\title{
The Relationship among Student's Domain of Learning Development Implementing Virtual Learning in Higher Learning Institutions
}

\author{
Nik Zulkarnaen Khidzir, Khairul Azhar Mat Daud, and Mohd Asrul Hery Ibrahim
}

\begin{abstract}
Virtual learning environments (VLEs) are the basic components of contemporary distance learning, but can also be integrated with a physical learning environment which may be referred to as blended learning. The success of a VLEs implementation depends to a considerable extent on student acceptance and use of such an e-learning system. Therefore, the aim of this study is to determine the relationship among domains of learning (cognitive, psychomotor and affective) of the student's in the implementation of VLEs in Higher Learning institutions. Through the purposive sampling techniques, questionnaires were distributed to 113 academic scholars in higher learning institutions (HLI) from various academic qualification, expertise and experiences. All hypothesis tested were significant. However, results of the correlation coefficient $(r)$ values $<0.4$ verifies that a weak positive relationship exists among all the domains of learning. Findings reveal that all the cognitive, psychomotor and affective skill influence each other. Through the findings, HLI practitioners and technologist could consider the ease use for VLEs in order to encourage the cognitive, psychomotor and affective skill development.
\end{abstract}

Index Terms-Virtual learning environment, cognitive, psychomotor, affective, correlation coefficient, higher learning institutions.

\section{INTRODUCTION}

A virtual learning environments (VLEs), or learning platform, is an e-learning education system based on the web that models conventional in-person education by providing equivalent virtual access to classes, class content, tests, homework, grades, assessments, and other external resources such as academic or museum website links. It is also a social space where students and teacher can interact through threaded discussions or chat. It typically uses Web 2.0 tools for 2-way interaction, and includes a content management system. In the future maybe more effective tools will be develop to enhance the capability of VLEs.

The success of a VLEs implementation depends to a considerable extent on student acceptance and use of such an e-learning system. The question is, how the approach could stimulate the growth of student's Learning Domains in higher learning institutions (HLI). Preliminary study to determine the relationship among domains of learning variables and

Manuscript received September 14, 2014; revised December 18, 2014.

Nik Zulkarnaen Khidzir and Khairul Azhar Mat Daud are with the Faculty of Creative Technology and Heritage, Universiti Malaysia Kelantan, Malaysia (e-mail: zulkarnaen.k@umk.edu.my).

Mohd Asrul Hery Ibrahim is with the Faculty of Entrepreneurship and Business, Universiti Malaysia Kelantan, Malaysia (e-mail: hery.i@umk.edu.my). discover how these variables influence each other's.

The finding could be significant to the improvement of the teaching and learning approach towards the development of student's cognitive ability, psychomotor and affective skill.

This paper explores mean score of each domain of learning variables (cognitive, psychomotor and affective). Appropriate quantitative analysis also conducted to test several hypotheses to determine the level of relationship among them. Related concept and previous literature also being reviewed to establish the scope of the study.

\section{LITERATURE REVIEW}

\section{A. Virtual Learning Environments (VLEs) Concepts}

VLEs are the basic components of contemporary distance learning, but can also be integrated with a physical learning environment [1] which may be referred to as blended learning. The terms VLE and learning platform are generically used to describe a range of integrated web based applications that provide teachers, learners, parents and others involved in education with information, tools and resources to support and enhance educational delivery and management. These terms are broadly synonymous with 'managed learning environments' (MLEs) and 'managed MVLEs. The applications that form part of these online services can include web pages, email, message boards and discussion forums, text and video conferencing, shared diaries, online social areas, as well as assessment, management and tracking tools [2]-[4].

The same context and helps promote and spread education plus learning activities on digital mediums on the web. With the advancement in technology the education sector has given a real positive boost to online education and this is the reason that online communication in the form of exchange of information exists between the teacher, student and the faculty with ease and without hassle through virtual learning environment [5].

In technical terms the most generic of definitions to sum up we can say that a virtual learning environment is a designed information space for education purpose [6].

\section{B. The Evolution of Virtual Learning Environments (VLES)}

Following the emergence of the internet technology in the early 1990s, various new tools, platforms and products have been developed to fully exploit its benefits. Since the mid-1990s the education community has witnessed the appearance of software products labelled VLEs that aim to support learning and teaching activities across the internet [7]. 
For example, popular commercial VLEs current being used in UK HE include Blackboard [8] and WebCT [9]. In this article, review on the evolution of VLEs from 1990s until 2010s. Table I highlight several literature about the evolution of VLEs.

\begin{tabular}{|c|c|c|c|}
\hline $\begin{array}{l}\text { Years/ } \\
\text { Era }\end{array}$ & $\begin{array}{l}\text { Product and } \\
\text { Solutions }\end{array}$ & Descriptions & Ref. \\
\hline 1991 & $\begin{array}{l}\text { The Smart } \\
\text { Board }\end{array}$ & $\begin{array}{l}\text { Offers an information space } \\
\text { that allows his students to } \\
\text { engage in active collaboration }\end{array}$ & {$[10]$} \\
\hline 1992 & $\begin{array}{l}\text { Full motion } \\
\text { video MPEG }\end{array}$ & $\begin{array}{l}\text { The first full motion video } \\
\text { MPEG compression methods } \\
\text { are developed and full motion } \\
\text { video becomes available for } \\
\text { all manner of digital programs }\end{array}$ & [11] \\
\hline 1997 & $\begin{array}{l}\text { The } \\
\text { Manhattan } \\
\text { Virtual } \\
\text { Classroom }\end{array}$ & $\begin{array}{l}\text { The earliest version of } \\
\text { "Manhattan" also supported a } \\
\text { few discussion groups and } \\
\text { private messaging. }\end{array}$ & [12] \\
\hline 2000 & $\begin{array}{l}\text { Web Course } \\
\text { in a Box }\end{array}$ & $\begin{array}{l}\text { Blackboard Inc. acquires Mad } \\
\text { Duck Technologies LLC, } \\
\text { developers }\end{array}$ & [13] \\
\hline 2002 & $\begin{array}{l}\text { Class Server } \\
3.0\end{array}$ & $\begin{array}{l}\text { Microsoft release Class Server } \\
3.0 \text { on June } 6 \text { Press release }\end{array}$ & [14] \\
\hline 2005 & $\begin{array}{l}\text { First online } \\
\text { doctoral } \\
\text { program in } \\
\text { music } \\
\text { education } \\
\end{array}$ & $\begin{array}{l}\text { Boston University launches } \\
\text { the first online doctoral } \\
\text { program in music education, } \\
\text { which within two years } \\
\text { admits nearly } 350 \text { students }\end{array}$ & [15] \\
\hline 2007 & $\begin{array}{l}\text { Meridian } \\
\text { Knowledge } \\
\text { Solutions }\end{array}$ & $\begin{array}{l}\text { Michigan Virtual University } \\
\text { launches a learning } \\
\text { management system from } \\
\text { Meridian Knowledge } \\
\text { Solutions to deliver training to } \\
\text { 150,000 Michigan } \\
\text { public-school teachers and } \\
\text { administrators and foster } \\
\text { collaboration among these } \\
\text { learners via online } \\
\text { collaboration spaces }\end{array}$ & [16] \\
\hline 2010 & $\begin{array}{l}\text { Chamilo } \\
\text { open-source } \\
\text { VLE }\end{array}$ & $\begin{array}{l}\text { Public release of Chamilo } \\
\text { open-source VLE, which is a } \\
\text { fork of Dokeos }\end{array}$ & [17] \\
\hline
\end{tabular}

The review had highlighted an active developments of VLE internationally. Therefore study toward the improvement of the VLEs implementation become an interest among researchers and technology implementer.

\section{Domain of Learning in Higher Learning Institutions (HLI)}

Benjamin Samuel Bloom (February 21, 1913 - September 13, 1999) was an American educational psychologist who made contributions to the classification of educational objectives and to the theory of mastery-learning. He also directed a research team which conducted a major investigation into the development of exceptional talent whose results are relevant to the question of eminence, exceptional achievement, and greatness [18].

Bloom et al. are well known for dividing categories of learning into the cognitive, affective, and psychomotor domains. The cognitive domain involves the learning and application of knowledge [19]. The affective domain addresses the acquisition of attitudes and values [20], and the psychomotor domain involves development of the body and skills it performs [21].
Most of higher learning institutions, these domains were widely adopted in the entire ecosystem of their teaching, learning environment as well as in the assessments approach. Table II briefly describe the domain description.

TABLE II: DOMAINS OF LEARNING

\begin{tabular}{llll}
\hline \hline & $\begin{array}{l}\text { Cognitive } \\
\text { Domain }\end{array}$ & $\begin{array}{l}\text { Psychomotor } \\
\text { Domain }\end{array}$ & $\begin{array}{l}\text { Affective } \\
\text { Domain }\end{array}$ \\
\hline & $\begin{array}{l}\text { Simulation } \\
\text { required }\end{array}$ & $\begin{array}{l}\text { Simulation } \\
\text { involved }\end{array}$ & $\begin{array}{l}\text { Allow } \\
\text { participant to } \\
\text { experience } \\
\text { Domain Description }\end{array}$ \\
& learners to & actions of the & participant, \\
& apply their & refined & feelings, \\
& cognitive & psychomotor & questions and \\
& skill & required & concern \\
\hline \hline
\end{tabular}

Source: Clark (1999)

\section{RESEARCH METHOdOLOGY}

A study using questionnaire survey was applied in this research. Five-Point-Likert-Scale was used to measure the Domains of Learning Development in Virtual Learning Environment implementation. Questionnaires were distributed to various fields of studies academic professional from various position and academic level in university through purposive sampling.

An empirical study was conducted to determine the cognitive, psychomotor and affective skills relationship as an outcome to the VLEs implementation in HLI. Primary data was collected using questionnaires as the data collection tool for the study. The validity of the research data collection tool was established through feedback from education practitioners and Technology Implementer professionals. Reliability tests were also conducted to ensure the appropriateness and consistency of data collection instrument for this study. Analysis of primary data was supported by the application of appropriate statistical techniques.

\section{RESEARCH MODEL AND HYPOTHESES}

A research model (Fig. 1) was developed focusing on the cognitive, psychomotor and affective skill for the implementation of Virtual Learning Environment in HLI.

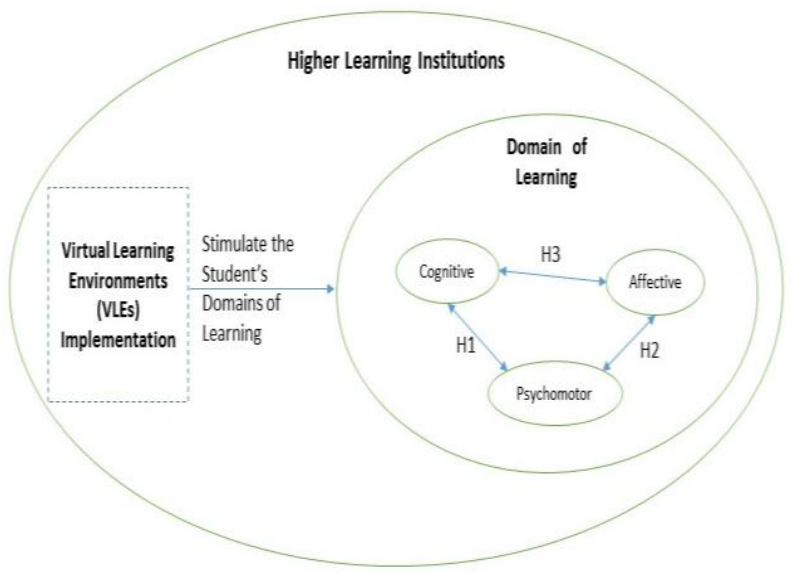

Fig. 2. Research model.

Based from research model in Fig. 2, three hypotheses have been developed to test the relationship between each Domains of Learning, cognitive, psychomotor and affective levels. The 
hypotheses are:

H1: There is a positive relationship between cognitive and psychomotor skill development

H2: There is a positive relationship between psychomotor and affective skill development

H3: There is a positive relationship between cognitive and affective skill development

\section{RESULTS DisCUSSIONS AND FINDINGS}

The survey questionnaire captured background data of respondent profile as well as their perception on the level of how the VLE could encourage the domains of learning development among students in Higher Learning Institution. Data collected from 113 academic, professional feedback were analyzed and discussed. The analysis and discussions are presented in two parts. Firstly, analysis of respondent's demographic profiles who participate in the study. Secondly, mean score for the level of academic professional perception how VLE could encourage the student's cognitive, psychomotor and affective skill development in university were analyze. Analysis for both of these primary data was supported by the application of appropriate statistical techniques. The analyses lead to several significant discoveries and expansion of existing knowledge. This section discusses the findings of the study in detail.

\section{A. Descriptive Analysis: Respondent's Demographics}

Respondent's demographic profile examined were respondent's personal academic qualification, their position level, domains of expertise, and field of teaching in university. Most of them are the academic professional from tutor to professors in HLI.

The demographic profile revealed some salient point. Essentially, the respondents were academician from different academic qualification and position in HLI. The majority of respondents owned a master degree as their highest qualification representing $60 \%$ of the sample population.

The profiling showed that a moderately significant number (45.1\%) had been appointed as Lecturer, $20.4 \%$ were Assistant Professor/ Senior Lecturer, $8.0 \%$ were Associate Professor and $3.5 \%$ were Professor. Respondents who participate in the survey also came from various domains of expertise. The majority of respondents from the population are experts in Social Sciences and others were expert in art and heritage, language studies, technology/engineering, health sciences/veterinary, natural sciences, computing/ICT/multimedia, business, management and entrepreneurship.

Therefore, the analysis shows that most of the respondent were consider as appropriate professionals that possess sufficient experience to response to the entire question trustfully and accurately. Table III summarized the demographic profiles of respondents involved in the study.

B. Virtual Learning Environment (VLEs) vs Field of Study Implementation Descriptive Analysis

Respondent's perceptions feedback on VLE implementation in HLI were collected from three major group field of studies consist of Art/Social Sciences; Business and
Entrepreneurship; and Science and Technology.

TABLE III: RESPONDENTS DEMOGRAPHIC PROFILES DATA

\begin{tabular}{|c|c|c|}
\hline \multicolumn{3}{|l|}{ Respondent's Demographic Items } \\
\hline Gender & Frequency & Percentage $(\%)$ \\
\hline Male & 53 & $46.9 \%$ \\
\hline Female & 60 & $53.1 \%$ \\
\hline Domains of Expertise & Frequency & Percentage (\%) \\
\hline Computing/ICT/Multimedia & 9 & $8.0 \%$ \\
\hline Business/Management/ & 21 & $18.6 \%$ \\
\hline Entrepreneurship & 28 & $24.8 \%$ \\
\hline Social Sciences & 16 & $14.2 \%$ \\
\hline Art and Heritage & 26 & $23.0 \%$ \\
\hline \multicolumn{3}{|l|}{ Language Studies } \\
\hline $\begin{array}{l}\text { Technology/Engineering/Industrial } \\
\text { Design }\end{array}$ & 6 & $5.3 \%$ \\
\hline Health Sciences/Veterinary & 6 & $5.3 \%$ \\
\hline Natural Sciences & 1 & $0.9 \%$ \\
\hline Academic Qualification & Frequency & Percentage $(\%)$ \\
\hline $\mathrm{PhD}$ & 34 & $30.1 \%$ \\
\hline Master & 60 & $53.1 \%$ \\
\hline Degree & 19 & $16.8 \%$ \\
\hline Designation & Frequency & Percentage (\%) \\
\hline Professor & 4 & $3.5 \%$ \\
\hline Assoc. Professor & 9 & $8.0 \%$ \\
\hline Assist. Professor/ Senior Lecturer & 23 & $20.4 \%$ \\
\hline Lecturer & 51 & $45.1 \%$ \\
\hline Assist. Lecturer & 5 & $4.4 \%$ \\
\hline Tutor & 21 & 18.6 \\
\hline TOTAL & 113 & $100 \%$ \\
\hline
\end{tabular}

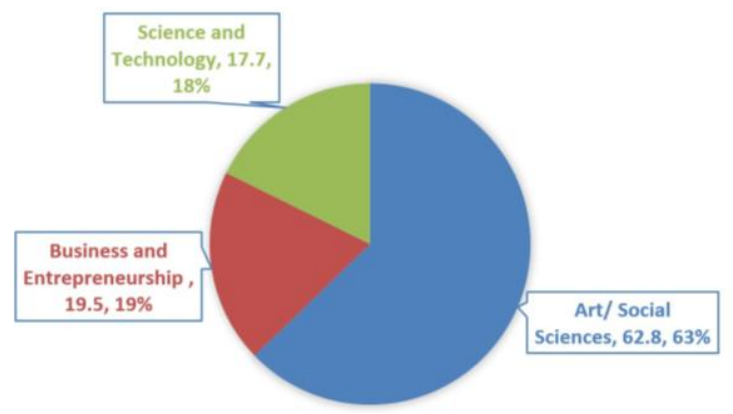

Fig. 2. Respondent's perceptions percentage.

Majority of $62.8 \%$ respondent realize that VLE could encourage student's Domains of Learning development in Art/Social Sciences Studies. While, $19.5 \%$ of the respondents aware that VLE could improve the student's Domains of Learning development in Business and Entrepreneurship Studies. But only minority of them (17.7\%) feel that VLE platform could not be implemented successfully in Science and Technology teaching and learning process. Fig. 2 illustrates percentage of perceptions from various field of studies.

Results of the analysis shows that the implementation of VLE in HLI could encourage better outcome for student's Domains of Learning variables (Cognitive knowledge, Psychomotor and Affective skills) development in art/social 
sciences compared to business/entrepreneurship; and science/technology curriculum. Therefore, the content of the curriculum and field of studies contributed to the respondent's perception on how effective VLE implementation. Additionally, there are other factors could influence their perception on VLE implementation such as design of the curriculum; level of knowledge or skills taught; operational policy; current technology and the virtual community exposure and experience using the platform.

\section{Reliability Test Results}

Cronbach's Alpha Coefficient was used to test the survey item's reliability. A coefficient value which is closer to " 1 " is required. Cronbach Alpha value for Domains of Learning (0.75) are high. Since all items in Table IV below had a reliability of more then 0.7 , the scale for these construct were considered to exhibit an acceptable reliability.

\begin{tabular}{lcccc}
\hline \multicolumn{4}{c}{ TABLE IV: RELIABILITY TEST RESULTS } & \\
\hline Construct & Variables & $\begin{array}{c}\text { No. of } \\
\text { Items }\end{array}$ & $\begin{array}{c}\text { Cronbach's } \\
\text { Alpha } \\
\text { Coefficient }\end{array}$ & $\begin{array}{c}N= \\
\text { Number of } \\
\text { Respondents }\end{array}$ \\
\hline $\begin{array}{l}\text { Domains of } \\
\text { Learning }\end{array}$ & $\begin{array}{c}\text { Cognitive } \\
\text { Psychomotor } \\
\text { Affective }\end{array}$ & 3 & 0.75 & 113 \\
\hline \hline
\end{tabular}

Therefore, the study emphasizes these three Domain of Learning variables; cognitive and psychomotor and affective. The results were measured and statistically analyzed to investigate the relationship between them.

\section{Domains of Learning Mean Score: Student's Cognitive and Psychomotor Skill Development}

Domains of Learning mean score for the implementation of VLEs were measured to determine student's cognitive, psychomotor and affective skill level.

As summarized in Table $\mathrm{V}$, the domains of learning variable cognitive skill development (3.78) level mean score was the highest for the implementation of VLEs in HLI. The results proved that the VLEs implementation is highly appropriate for student's cognitive skill development.

Meanwhile, domains of learning variables affective skill development (3.46) level mean score was second highest for the implementation of VLEs in HLI. Respondent believes that affective skill could be trained through a Virtual Learning Environment effectively.

TABLE V: MEAN SCORE FOR DOMAINS OF LEARNING VARIABLES COGNITIVE AND PSYCHOMOTOR IN VIRTUAL LEARNING ENVIRONMENTS (VLES)

\begin{tabular}{lccc}
\multirow{2}{*}{$\begin{array}{l}\text { Domains of } \\
\text { Learning }\end{array}$} & \multicolumn{3}{c}{ VLEs Implementation } \\
\cline { 2 - 4 } & $N$ & Mean & Std. Dev. \\
\hline Cognitive Skill & 113 & 3.78 & 0.729 \\
\hline Psychomotor & 113 & 3.27 & 0.879 \\
\hline Affective & 113 & 3.46 & 0.890 \\
\hline \hline$N=$ No. of Respondents & &
\end{tabular}

Another domains of learning variables depicted the lowest, psychomotor (3.27) level for the implementation of VLEs.

Results of the analysis show the evidence of how influence the implementation of the VLEs could encourage the domains of learning variables. The findings could assist education technology implementer to improve their solution by looking into better cognitive, psychomotor and affective skill development.

E. Analysis of the Relationship between Cognitive, Psychomotor and Affective Skill Development for the Implementation of Virtual Learning Environments (VLEs) in Higher Learning Institution (HLI)

The Bivariate Pearson Correlation test was then conducted on the formulated research hypotheses to determine the significant relationship, strength and direction of the integrity and availability of information asset for each ICT Outsourcing phase. The correlation coefficient values, $(r)$ was derived to explain the relationship strength between them. A result of $p$-value $<0.01$ is considered significant. A weak relationship is indicated by a $(r)$ value of less than 0.4 , values between 0.4 and 0.7 indicate moderate relationship and a strong relationship has a value higher than 0.7 .

As revealed in Table VI, the results of the hypotheses tests indicate positive correlations for the three hypotheses. $\mathrm{H} 1, \mathrm{H} 2$, and H3 were accepted and the null was rejected based on significant $p$-value $<0.01$. The correlation coefficient $(r)$ values is 0.381 for $\mathrm{H} 2$ was the highest compared to $\mathrm{H} 1$ and $\mathrm{H} 3$. As for $\mathrm{H} 1$, the correlation coefficient $(r)$ is 0.305 was the lowest. Meanwhile, the correlation coefficient $(r)$ is 0.377 .

TABLE VI: HyPOTHESES TEST RESULTS FOR THE SIGNIFICANT RELATIONSHIPS BETWEEN INTEGRITY AND AVAILABILITY OF KEY INFORMATION ASSETS

\begin{tabular}{cccll}
\hline \hline Hyp. & $\begin{array}{l}\text { Correlation } \\
\text { Coefficient }(r)\end{array}$ & $\begin{array}{l}\text { Sig. } \\
(p \text {-value })\end{array}$ & Decision & Results \\
\hline $\mathrm{H} 1$ & 0.305 & $0.001^{*}$ & Significant & $\begin{array}{l}\text { Weak +ve } \\
\text { Relationships }\end{array}$ \\
\hline $\mathrm{H} 2$ & 0.381 & $0.000^{*}$ & Significant & $\begin{array}{l}\text { Weak +ve } \\
\text { Relationships }\end{array}$ \\
\hline $\mathrm{H} 3$ & 0.377 & $0.000^{*}$ & Significant & $\begin{array}{l}\text { Weak +ve } \\
\text { Relationships }\end{array}$ \\
\hline
\end{tabular}

*Correlation is Significant at the 0.01 levels (2-tailed)

All the significant hypotheses described weak positive relationship strength among all the domains of learning variables (Cognitive, Psychomotor and Affective) skills hypotheses tested.

\section{CONCLUSION}

This study empirically establishes the significant relationship among three domains of learning (cognitive, psychomotor and affective) for the implementation of VLEs in HLIs. Literatures highlight several evidences about the evolution of VLEs, technology involved and its implementation in HLI.

Hypothesizes results provide significant evidence of relationship strength and direction among three domain of learning variables. Furthermore, the empirical analysis on Domains of Learning variables for VLEs implementation in HLI could provide a measurable indicator to discover level of how cognitive, psychomotor and affective skill development influence each other's.

Eventually, the findings possibly will provide an empirical evidences for the improvement to practitioner and technology 
implementer. Understanding the relationship pattern among these three domains of learning will enable academic professionals, technology providers and practitioners prioritize related issues effectively.

\section{ACKNOWLEDGMENT}

The authors wish to thank Faculty of Creative Technology and Heritage, Universiti Malaysia Kelantan for their financial support in this study. Special thanks are also due to the Faculty of Creative Technology and Heritage for the sponsorship to participate in ICIET 2015.

\section{REFERENCES}

[1] P. Dillenbourg, "Virtual learning environments," presented at the EUN Conference 2000: Learning in the New Millennium: Building New Education Strategies for Schools, 2000.

[2] Briefing Paper 1: MLEs and VLEs Explained, JISC, 2007.

[3] JISC. (2002). Inform1. [Online]. Available: http://www.jisc.ac.uk/publications/publications/pub_inform1.aspx.

[4] Whatis techtarget. [Online]. Available: http://whatis.techtarget.com/definition/virtual-learning-environmentVLE-or-managed-learning-environment-MLE

[5] Edutechwiki. [Online]. Available: http://edutechwiki.unige.ch/en/Virtual_learning_environment

[6] Tecfa. [Online].

Available: http://tecfa.unige.ch/tecfa/publicat/dil-papers-2/Dil.7.5.18.pdf

[7] R. O'Leary, "Virtual learning environments (VLEs)," LTSN Economics and Manager of Learning Technology Support Service, University of Bristol.

[8] Blackboard. (September 11, 2014). [Online]. Available: http://www.blackboard.com

[9] Webct. (September 11, 2014). [Online]. Available: http://www.webct.com

[10] J. Johnson-Eilola, Datacloud: Toward a New Theory of Online Work, Cresskill, NJ: Hampton Press, Inc., 2005.

[11] N. Higgett and A. McNamara, "Multimedia design: Teaching a new design discipline," September 10, 2014.

[12] S. Narmontas, History of Manhattan Virtual Classroom, Western New England College, 1997.

[13] MadDuck Technologies LLC, Networked Learning Environment The Blackboard Learning System - and Blackboard History, September 10, 2014.

[14] Microsoft. (September 10, 2014). [Online]. Available: http://www.microsoft.com/en-us/news/press/2003/jun03/06-05classse rver30pr.aspx
[15] D. G. Hebert, "Five challenges and solutions in online music teacher education," Research and Issues in Music Education, vol. 5, 2007.

[16] Michigan University Chooses Meridian. (September 10, 2014). [Online]. Available: http://www.govtech.com/education/-Michigan-Virtual-University-Ch ooses-Meridian.html

[17] Chamilo. (September 11, 2014). [Online]. Available: http://www.chamilo.org/en/about-chamilo

[18] B. S. Bloom, Developing Talent in Young People, New York: Ballantine Books, 1985

[19] B. Bloom, "Taxonomy of educational objectives," Handbook I: Cognitive Domain, New York: McKay, 1956.

[20] D. Krathwohl et al., "Taxonomy of educational objectives," Handbook II: Affective Domain, New York: McKay, 1956.

[21] Jewett et al., "Educational change through a taxonomy for writing physical education objectives," Quest 15, pp. 35-36, 1971.

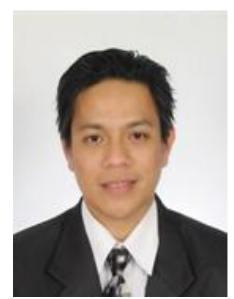

Nik Zulkarnaen Khidzir is a senior lecturer and the deputy dean (Student Affairs and Entrepreneurship) in Faculty of Creative Technology and Heritage, Universiti Malaysia. He has been involved in ICT industry for the past 14 years. He was graduated in computer science degree and diploma specialize in software engineering, and master's degree (MSc. IT) specialized in information privacy and ICT strategic planning, and his $\mathrm{PhD}$ in information security risk management provide him a necessary skill for research and consultation works.

His research interests are in software engineering, information security risk management, business and education computing/e-commerce and cyberology. Cyberology is a nobel growing, interesting and potential areas to explore and discover in the next future comes. He started his professional career as Technical Writer involved in Bank Muamalat Malaysia Berhad Banking System Migration Project. Throughout his years of experiences in industry, he also involved in telecommunications, digital Multimedia content development, and System Integrator and ICT solution provider as System Analyst, Database Administrator, Software Tester, Software Designer, Assistant Project Manager (ICT-related project). Also involved in research and consultation as well as training program development for academia and industry.

In academia, he is actively involved in organizing the academic conferences local and international such National Postgraduate Seminar 2010 and International Information Technology Conference 2013. He also becomes as proceeding conference and journal reviewer local and international. Pertaining his research interest and contribution to the body of knowledge, he has published several articles in indexed proceedings and journals. He is a member of the IACSIT, IEEE and PECAMP. 